\title{
O julgamento da adpf 153 pelo stf à luz da filosofia da memória política: narrar os fatos, juntar os trapos e lembrar para não esquecer \\ Adpf 153 judgment by stf in the light of the philosophy of political memory: narrate the facts, join the rags and remember not to forget
}

\section{Nelson Camatta Moreir ${ }^{1}$ \\ Raoni Vieira Gomes ${ }^{2}$}

\begin{abstract}
Resumo: O presente artigo formula uma análise crítica do julgamento da ADPF 153 pelo STF, dando ênfase aos votos do Ministro Relator e do Ministro que abriu a divergência. Sob a perspectiva da filosofia política da memória de Walter Benjamin, buscou-se apresentar a
\end{abstract}

1 Pós-doutor em Direito pela Universidad de Sevilla. Pós-doutor em Direito em Direito pela Universidade do Vale do Rio dos Sinos (Unisinos). Doutor em Direito pela Unisinos, com estágio anual na Universidade de Coimbra. Mestre em Direito pela Unisinos. Professor do Programa de Pós-Graduação Stricto Sensu (doutorado e mestrado) e da graduação em Direito da Faculdade de Direito de Vitória (FDV-ES). Líder do Grupo de Pesquisa CNPq Teoria Crítica do Constitucionalismo, da FDV. Líder do Grupo de Estudos Direito e Psicanálise (FDV-ES/Escola Lacaniana de Psicanálise de Vitória). Profesor Invitado, adjunto al Programa Academic Visitor de la Facultad de Derecho de la Universidad de Sevilla. Miembro del Grupo de Investigación Antagónicos de la Facultad de Derecho de la Universidad de Sevilla. Membro Honorário e Vice-presidente da Rede Brasileira Direito e Literatura (RDL).

2 Advogado. Especialista em Ciências Criminais pela FDV, Mestrando em Direitos e Garantias Fundamentais pela FDV 
relevância do narrador e da narrativa por este formulada, como alternativa à reconstrução de um passado que teima em não passar. Buscou-se entabular crítica à manutenção da lei da anistia, desvelando algumas das suas consequências para contemporaneidade brasileira. O presente artigo buscou apresentar uma hipótese de diagnóstico das consequências da opção pela anistia ampla, geral e irrestrita e da sua manutenção pelo STF.

Palavras-chave: Memória; ADPF 153; Narrador; Walter Benjamin.

Abstract: This article intends to formulate a critical analysis on the judgment of ADPF 153 by STF, emphasizing the votes of the Minister Relator and of the Minister who opened the divergence. From Walter Benjamin's perspective of the political philosophy of memory, we sought to present the relevance of the narrative for the reconstruction of a past that it is not going to pass. With emphasis on the role of the narrator, it was ambitious to build a critique of the amnesty maintained in the court reviewed and its consequences for Brazilian contemporaneity. The present article sought to present a hypothesis for the diagnosis of the consequences of the option for broad, general and unrestricted amnesty and its maintenance by the Supreme Court.

Keywords: Memory; ADPF 153; Narrator; Walter Benjamin

\section{Introdução}

No presente artigo ambiciona-se a construção de um breve estudo jurídico-político da memória, como forma de enfrentamento do esquecimento forçado pelos que ainda não cessaram de vencer. 
Para tanto, no capítulo inicial desenvolve-se uma conceituação do que se entende por memória, bem como seus aspectos e relevâncias no contexto sócio-político da realidade brasileira.

Neste sentido, ganha relevância a crítica formulada por Walter Benjamin ao progresso, uma vez que é necessário romper a crença na história como uma linear continuidade. À marcha do progresso, Benjamin formula críticas nas teses Sobre o Conceito de História, sua derradeira obra. Na tese VII, Benjamin (2016, p. 12) defende "escovar a história a contrapelo", que significa dizer que a história deve ser contada sob a perspectiva dos vencidos, aqui representados pelas vítimas da ditadura civil-militar no Brasil.

Ainda no capítulo inicial, são apresentadas as visões de Walter Benjamin e Paul Ricoeur sobre o narrador. Benjamin o aborda em uma perspectiva histórica e filosófica, atribuindo ao ofício do narrador a defesa contra o avançar do progresso. Ricoeur, por sua vez, dedica-se mais às questões relativas ao tempo, em sua articulação com a narrativa e à como o tempo e a narrativa podem concatenar experiências.

Portanto, servindo-se do viés político e histórico das teses, torna-se nuclear a pujança da filosofia política de Benjamin, bem como os caminhos que sugere como alternativas à história oficial. Estes, por sua vez, manifestam-se na figura do narrador, com a premente necessidade de remar contra a maré, tendo como norte o testemunho e a tradição que os vencidos carregam.

No que se refere ao viés político, a vitória dos derrotados só virá na luta contra o continuum, pois, caso se continue a contá-la no sentido do pelo, "a história produzirá novas guerras, novas catástrofes, novas formas de barbárie e de opressão" (LOWY, 2005, p. 74).

Neste trilho, apresenta-se com relevância a figura do narrador, a fim de coadunar uma narrativa com o acontecido 
e permitir ao leitor formar sua opinião ante o relato daqueles que sentiram o peso da história.

No capítulo seguinte desenvolve-se uma análise sobre o julgamento da ADPF 153 pelo STF, no qual se decidiu pela constitucionalidade do $\S 1^{\circ}$, do art. $1^{\circ}$, da lei $6683 / 79^{3}$, impedindo o julgamento e a revisão dos crimes comuns conexos aos crimes políticos cometidos no período compreendido entre 02 de setembro de 1961 e 15 de agosto de 1979.

Tendo em vista que importa ao presente artigo a visão política da anistia, cuja gênese vem da palavra grega amnestia (esquecer), torna-se também relevante apresentar alguns momentos em que a anistia figura no Ordenamento Pátrio, a saber, na Constituição Federal de 1988, nos arts. 21, XVII e 48, VIII, dentre as competências da União e do Congresso Nacional, respectivamente. Ela também está presente no Código Penal, talhada no art. 107, II. Nas três previsões supracitadas, a anistia figura como perdão, podendo ser concedido pelo Presidente, pelo Congresso Nacional e pelo Judiciário, portanto, os três poderes da República podem conceder anistia, podem promover e/ou forçar o esquecimento.

Nesta toada, no terceiro capítulo formula-se breve crítica acerca dos riscos assumidos com o resultado do julgamento da ADPF da Lei da Anistia, notadamente no impedimento da construção no imaginário social do simbolismo da visão dos atores da ditadura civil militar sentados no banco dos réus.

3 Art. $1^{\circ}$ É concedida anistia a todos quantos, no período compreendido entre 02 de setembro de 1961 e 15 de agosto de 1979, cometeram crimes políticos ou conexo com estes, crimes eleitorais, aos que tiveram seus direitos políticos suspensos e aos servidores da Administração Direta e Indireta, de fundações vinculadas ao poder público, aos Servidores dos Poderes Legislativo e Judiciário, aos Militares e aos dirigentes e representantes sindicais, punidos com fundamento em Atos Institucionais e Complementares.

$\S 1^{\circ}$ - Consideram-se conexos, para efeito deste artigo, os crimes de qualquer natureza relacionados com crimes políticos ou praticados por motivação política. 
No Brasil, mais de 60 mil pessoas morrem vítimas da violência todos os anos ${ }^{4}$, sem, entretanto, terem suas histórias contadas à contra pelo. O que permanece é a reminiscência das suas mortes reduzidas aos seus círculos familiares.

É por conta disso que a empreitada que se segue ambiciona relacionar o Direito, a filosofia política, a memória e o esquecimento forçado, de modo que fiquem evidenciadas suas notáveis imbricações, materializadas no presente espaço na figura do narrador, conforme ensina Walter Benjamin 5 .

Neste trilho, apresenta-se a memória como alternativa à barbárie que se anuncia, pois é através de um trabalho de rememoração, cuja condição de possibilidade é a existência da lembrança, que se pretende associar os "avisos de incêndio" que o cotidiano brasileiro tem emitido (MOREIRA e DE PAULA, 2016, p. 159).

Diante do que se oportuniza debater no presente artigo, indaga-se: é possível enfrentar o avanço do autoritarismo através de um trabalho de rememoração política de um passado que é levado ao esquecimento forçado?

4 Disponível em: <https://noticias.uol.com.br/cotidiano/ultimasnoticias/2018/08/09/numero-de-mortes-violentas-no-brasil-cresce-e-chegaa-63-mil-em-um-ano.htm> Acesso em 07 de dezembro de 2018.

5 Em Sobre o Conceito de História o filósofo alemão advoga a tese de que a história deve ser contada sob a perspectiva dos vencidos, em contraponto à história oficial que lega aos vencedores o protagonismo, ignorando os escombros que ficam pelo caminho, os corpos estendidos no chão, que clamam por ajuda, que clamam por ouvintes e narradores. 


\section{A importância da memória política como an- tagonista do esquecimento forçado: lembrar para não repetir}

O povo brasileiro vive às voltas com o assunto da ditadura civil militar, que foi de 1964 a 1985. Entretanto, embora tenham ocorrido severas violações de direitos civis e sociais ${ }^{67}$, o debate sobre tais causas e consequências teima em ser silenciado. Ao evitar o reconhecimento da importância de se rememorar o passado recente, suas narrativas e testemunhos, perde-se o fio da história e assume-se o risco de repetir o passado não democrático, autoritário.

Neste sentido, busca-se seguir na contramão dos que tentam esquecer o passado, encobrir as violações e atrocidades perpetradas naquele tempo, apoiados em um esquecimento forçado, materializado na lei da anistia. Pois, defender-se-á que a memória dos 21 anos de ditadura de todo o mal cometido não deve ter seus rastros apagados. Talvez por isso Jean Marie Gagnebin afirme: “a exceção que constitui a política de memória do governo brasileiro, bem como suas estratégias extremas de esquecimento maciço em relação à ditadura militar de 1964 a 1985 parecem fazer parte de meticulosas tentativas de impor o esquecimento" (GAGNEBIN, 2014, p. 251).

6 Mais de 400 pessoas foram mortas e ou desapareceram por conta de atos promovidos pela ditadura civil militar e seus prepostos. Disponível em: <http://agenciabrasil.ebc.com.br/direitos-humanos/noticia/2014-12/ comissao-reconhece-mais-de-200-desaparecidos-politicos-durante> Acesso em 26 de novembro de 2018. Disponível em:

7 <http://www.memoriasreveladas.gov.br/administrator/components/ com_simplefilemanager/uploads/CNV/relat\%C3\%B3rio $\% 20$ cnv $\% 20$ volume_1_digital.pdf> Acesso em 26 de novembro de 2018. O relatório da Comissão Nacional da Verdade disseca as violações de direitos perpetrados pela ditadura militar. 
A peculiar análise da filosofia da história formulada por Walter Benjamin (2016, p. 11), talhada na obra Sobre o Conceito de História, representa o norte teórico a embasar a filosofia política da memória adotada no presente artigo, notadamente a Tese VI:

Articular historicamente o passado não significa 'conhecê-lo como ele verdadeiramente foi'. Consiste, muito antes, em adornar-se de uma recordação tal como ela brilha num instante de perigo. A incumbência do materialismo histórico é fixar uma imagem do passado, imagem que se apresenta sem avisar o sujeito histórico no instante do perigo. O perigo ameaça tanto a existência da tradição como aqueles que a recebem. Para esta e para estes o perigo é o mesmo: prestar-se a ser instrumentos da classe dominante. Em cada época é preciso esforçar-se por arrancar de novo a tradição do conformismo que pretende avassalá-la. O messias não vem só como redentor; ele também vem como vencedor do Anticristo. $\mathrm{O}$ dom de acender no passado a chispa da esperança só é dado ao historiador perfeitamente convencido de quem nem sequer os mortos estarão seguros se o inimigo vencer. E esse inimigo não parou de vencer.

Tendo em vista que até mesmo os mortos estarão em perigo se o inimigo seguir vencendo, toma-se a Tese VI como exemplo neste contexto, pois, segundo Reyes Mate, o perigo do qual fala Benjamin é a memória, a qual, justamente por meio da anistia, parecem tentar fazer-se esquecida, afinal "a memória significa considerar o passado declarado insignificante como parte fundamental da realidade" (MATE, 2011, p. 156).

Na obra de Márcio Seligman-Silva (2006) a memória mostra-se como alternativa, como uma das possibilidades de enfrentamento do passado que fica pelo caminho, ante a impiedosa marcha do progresso:

(...) a memória pensada em sua chave política, jurídica e moral não pode ocultar o fato de que ela é também memória antropológica. 
Nunca é demais insistir no fato de que a luta pela justiça se da em diferentes níveis, todos distintos e ao mesmo tempo determinantes entre si: o da memória e história da sociedade, o da memória de grupos sociais e o da memória dos familiares. A luta de Antígona é tanto familiar como cívica. Do mesmo modo, no campo histórico, a luta pela restituição dos corpos dos 'desaparecidos' na ditadura, a luta pela restituição da verdade e a luta pela justiça, deve levar em conta estes diversos níveis de relacionamento com o passado.

Para Paul Ricoeur (2003, p. 6), a reapropriação do passado histórico requer um cuidado com a origem das memórias e a maneira com que esta é instruída pela história contada:

A memória coletiva não está privada de recursos críticos; os trabalhos escritos dos historiadores não são os seus únicos recursos de representação do passado; concorrem com outros tipos de escrita: textos de ficção, adaptações ao teatro, ensaios, panfletos; mas existem igualmente modos de expressão não escrita: fotos, quadros e, sobretudo, filmes (pensemos em Shoah de Claude Lanzmann, em A Lista de Schindler de Spielberg). Além disso, o gênero retrospectivo próprio à história concorre com os discursos prospectivos, os projetos de reforma, as utopias; em suma, concorre com os discursos voltados para o futuro. Os historiadores não devem esquecer que são os cidadãos que fazem realmente a história - os historiadores apenas a dizem; mas eles são também cidadãos responsáveis pelo que dizem, sobretudo quando o seu trabalho toca nas memórias feridas. A memória não foi apenas instruída, mas igualmente ferida pela história.

Pretende-se "reconhecer o risco político e social que se corre quando o trabalho de memória e reconstrução histórica de uma nação não é preservado, estimulado, revisado, enfim, (re) construído cotidianamente (...) pois é do esquecimento que se permite a reescrita da história, mas uma reescrita desvirtuada, desprendida da verdade fatual que originou a história" (OLIVEIRA e GOMES, 2017, p. 82-83).

Neste passo, o estudo da memória, sob o prisma da filosofia política, pode apontar relevantes caminhos para o 
encontro da sociedade brasileira com o que se força esquecer. Pois o que não é debatido, conversado, falado e ouvido publicamente corre o risco de se repetir, ou até mesmo de seguir acontecendo.

Ademais a relevância da memória, como antítese ao esquecimento, contem múltiplos valores éticos, de relevância coletiva:

(...) contra esta tendência de esquecimento, exclusão e restrição de direitos, que resultaram e ainda resultam em práticas insidiosas de violência (propiciando, por outro lado, uma contra-violência) é preciso reforçar as falas de recuperação da memória, de alteridade e de preservação de direitos humanos a fim de que sejam geradas visibilidade e inclusão para os grupos vulneráveis (BREPOHL, 2018, p. 325).

Evidencia-se, portanto, a "urgência no homem contemporâneo de compreender o fardo e o trabalho da memória como dimensão fundamental da existência, identificada na crescente obsessão pelo reconhecimento da identidade e da diferença a fim de pensar maneiras de assimilar e apreender o outro" (DURAN e BENTIVOGLIO, 2013, p. 215), pois "de subsidiária, a memória teria sido potencializada como um dos sujeitos da história" (DURAN e BENTIVOGLIO, 2013, p. 229).

Acrescenta-se que a memória tem em sua formação o testemunho dos que a compõem, o falar, o ouvir, o narrar os fatos vividos, mesmo os fatos passados de pais para filhos, em uma tradição familiar, são relevantes para construção político social da memória coletiva, pois o que não é conversado, debatido, permanecerá ocultado e longe do conhecimento do outro.

Entretanto, os autoproclamados vencedores parecem trabalhar pelo esquecimento da memória dos vencidos, das vítimas, agindo para controlar a narrativa sobre o período 
da ditadura civil militar, por meio do discurso do progresso, manifestado no apagar do passado.

Neste sentido, segue Gagnebin (2014. p. 253):

No Brasil, as vítimas não tomaram a palavra. Primeiro, pela simples razão de que não existe nenhum estatuto de vítima; de que nenhum texto oficial, de lei ou de história, usa essa palavra, a qual, por sua vez, acarreta uma pergunta complementar: quem foram os carrascos?

Ora, como houve a anistia, o silenciamento das vítimas, sequer se permite à sociedade saber quem foram os algozes.

A palavra das vítimas dos "terríveis anos" 8 é tratada com desdém, irrelevância, o que visa esconder o peso que seus testemunhos teriam, posto que, mantida a lógica que ainda vige "o vencedor é o dono da verdade, pode manipulá-la como lhe convier" (LEVI, 2004, p.11). Sucede que as vítimas também foram esquecidas, sequer puderam apresentar suas versões, sendo que muitas, como está comprovado, não tiveram seus corpos encontrados ${ }^{9}$. Fossem levados aos bancos dos réus os responsáveis pelos crimes da ditadura seria facultado às vítimas, às testemunhas, aos réus, à sociedade, falar, ouvir e debater sobre aquele período, entretanto, com o silêncio forçado, perde-se o fio da história, desvalorizando-se as narrativas que ficam pelo caminho.

Ganha relevância, pois, o testemunho das vítimas diretas e indiretas do arbítrio, do autoritarismo, afinal:

O testemunho, contudo, é concebido por Levi como lembrança que evita a repetição (...). O trabalho do testemunho, desde o inicio consciente, realiza uma elaboração a contrapelo, de traz para

8 Nesta matéria jornalística há relatos sobre o proceder da ditadura, a qual está disponível em: <https://exame.abril.com.br/brasil/7-relatos-chocantessobre-a-tortura-na-ditadura-no-brasil/> Acesso em 11 de dezembro de 2018.

9 Disponível em: <https://ultimosegundo.ig.com.br/politica/2014-12-10/ comissao-da-verdade-confirma-434-mortes-e-desaparecimentos-naditadura.html> Acesso em 06 de dezembro de 2018. 
frente, pois parte da lembrança do genocídio para dissolver as tendências à sua repetição (...). Esse trabalho testemunhal, portanto, não resulta na lembrança do sentimento ou desejo recalcado, como na clínica; mas é, sim, executado com base na lembrança para elaborar conscientemente o impeditivo ético da repetição histórica (...) (AQUINO, 2013, p. 124).

Logo, ignorar a palavra das vítimas impõe uma lógica de coerção ao esquecimento, levando a um regime que se perpetua, que dura e que contamina o presente. Trata-se não apenas de um caso de recalque social e político violento, mas também da "naturalização da violência como grave sintoma social no Brasil", como afirma a psicanalista Maria Rita Kehl citada por Gagnebin (2014, p. 255).

Neste ínterim evidencia-se que "vivemos numa cultura da amnésia e farão falta muita energia para pensar a ética e a política, o direito e a justiça, a verdade e a beleza a partir da memória dos vencidos" (REYES MATE, 2011. p. 167).

E isto se dá na medida em que há um continuum entre os que lutaram pela democracia e a atual em que se vive, uma vez que morreram muitos para que hoje estejamos sob o império da democracia: "O que Benjamin quer nos dizer é que, sem a memória e o reconhecimento dessas mortes, nunca entenderemos o que agora desfrutamos" (REYES MATE, 2011, p. 102). Afinal, "a memória pode conseguir que, de geração em geração, se mantenha viva a consciência da injustiça passada e, portanto, a necessidade de que se faça justiça" (REYES MATE, 2011, p. 103).

Uma das formas de se alcançar o exercício da concretização da memória, se dá por meio do narrador, figura determinante à teoria benjaminiana, porquanto apresenta o contar da história através dos relatos dos que a viveram, arrimados nas tradições que vão ficando pelo caminho, ouvindo e recontando os testemunhos pretéritos. $\mathrm{O}$ avançar insano do progresso fez com se "abatesse sobre as pessoas 
uma forma de pobreza totalmente nova. (...) A nossa pobreza de experiência é apenas uma parte da grande pobreza que ganhou um novo rosto", afinal "de que nos serve toda a cultura se não houver uma experiência que nos ligue a ela?" (BENJAMIN, 2016, p. 85). É justamente através do narrador benjaminiano que a experiência deve ser passada adiante.

\subsection{A importância do narrador que conta a his- tória a contrapelo.}

Walter Benjamin elegeu Nikolai Leskov como modelo de narrador ideal, posto que o via como um artífice da palavra, criativo contador de histórias as quais desenvolvia por meio do conhecimento e da tradição. A predileção de Benjamin por Leskov se deu devido à sua proximidade com o povo, do modo como ele narrava a alma do povo russo, e sua cultura popular, ao contrário do que permeava a literatura dos romancistas da sua época. Leskov, segundo Benjamin, encarnava o que ficava de fora, a literatura periférica, tendo em vista que seus textos relatavam a vida popular, materializado numa narrativa à margem das tendências individualistas do seu tempo. Portanto, a narrativa de Leskov o situava no sentido oposto ao do romance, que seria a forma comezinha da literatura burguesa, afinal tal literatura emergia do "individuo isolado, que não pode mais falar exemplarmente sobre suas preocupações mais importantes e que não recebe conselhos nem sabe da-los" (BENJAMIN, 1994, p. 201).

Nesta obra, Benjamin propõe uma narração a partir das ruínas, uma transmissão entre os cacos, de uma tradição em migalhas. Não em vão vê o narrador como humilde, representado na figura do trapeiro, do sucateiro, daqueles que pegam os fragmentos da história, os restos, os detritos, 
o que não entrou na versão oficial, aquilo que é visto como sem importância nem sentido. Pois, para Benjamin, o narrador e o historiador deveriam transmitir o que a tradição, oficial ou dominante, justamente não recorda (GAGNEBIN, 2014, p. 88).

No sentir de Sara Hartman (2015, p. 14) os avisos formulados pela peculiar filosofia da história de Benjamin se voltam também à crítica na crença no progresso - conceito do qual o presente artigo se vale - na medida em que o avançar da história brasileira ignora as vítimas do período ditatorial:

O fim da narração tradicional - tematizado pela literatura, pela história e pela filosofia moderna e contemporânea - é percebido por Benjamin como parte do declínio de toda uma modalidade de experiência tradicional, cuja visão de mundo era passível de ser compartilhada. As suas análises tinham como horizonte o que se estava fazendo do futuro à época presente, ou seja, o início do século XX. É em meio às intensas transformações de tal período que o autor sinaliza a emergência da ideologia do progresso, que tem no domínio do passado um importante elemento de sua afirmação.

Contudo, outra obra de Benjamin também é dotada de relevância no que concerne ao papel do narrador, e em Experiência e Pobreza a perda da experiência é novamente abordada, desta vez:

Repousa sobre a possibilidade de uma tradição compartilhada por uma comunidade humana, tradição retomada e transformada, em cada geração, na continuidade de uma palavra transmitida de pai para filho. A importância dessa tradição, no sentido concreto de transmissão (...). (GAGNEBIN, 2014, p. 84).

Ainda trilhando neste caminho, Gagnebin aponta que:

A exigência de memória deve levar em conta as grandes dificuldades que pesam sobre a possibilidade da narração, sobre a possibilidade da experiência comum, enfim, sobre a possibilidade da transmissão e do lembrar. Se passarmos em silêncio sobre elas 
o discurso de memória corre o risco de ser rapidamente confiscado pela história oficial. (GAGNEBIN, 2014, p. 89).

Neste sentido, entende-se a narrativa pregada por Benjamin numa relação com o não esquecimento, tendo o lembrar como forma de construir o futuro, Antonio Leal de Oliveira (2017, p. 249) acrescenta que:

Conforme Benjamin deixará claro em seus textos, a narrativa atua de modo a fugir dos encadeamentos causais, desses que só escrevem a história depois de ocorrida. Nesse sentido, a narrativa irá questionar as supostas precisões da ciência histórica, ela trará de forma indistinta história individual e coletiva, uma vez que "conjuga o passado (subjetivo) com o choque atual (a sociedade de massa e de consumo, o fascismo, a ciência, a técnica, etc.)". Em suma, na narrativa há o encontro do que passado com o presente, o que foi com o que está sendo. (MATOS, 2002, p.305).

Contar a história, narrar/testemunhar o acontecido é de fundamental importância, pois é a forma de dar sentido àquilo que, se não fosse contado, permaneceria como uma sequência de acontecimentos. A narrativa é redentora, ela reconcilia e estabelece o acordo com as coisas como realmente são. Neste prisma, afirma-se que somente com a memória, só com a lembrança dos fatos passados, é possível se imaginar, consequentemente narrar e, por fim, reconciliar-se com esse passado que te empurra até o futuro.

Sarah Hartman (2015, p. 18) analisa a perspectiva do narrador para Benjamin e Ricoeur e aponta as transformações suportadas pela narração, notadamente as narrativas históricas e literárias, mostrando como elas podem articular experiências temporais significativas por meio de uma redoma de configuração e reconfiguração que inclui, a grosso modo, o mundo, a obra e o leitor/ouvinte.

Aspira, ainda, demonstrar de qual forma a narrativa pode pronunciar experiências através da formação de uma 
trama literária. Pois o autor francês ponderava a morte da arte de narrar como um período crítico que não encontrava um fim em si mesmo, tendo consequências ainda não completamente avaliadas. Para tanto, seu trabalho partia da premissa de que narrar é sempre realizar uma construção temporal (HARTMAN, 2015. p. 18).

É por meio do narrar que o tempo se torna humano, logo, conta a mediação entre tempo e "mímesis (o dado prefigura, o artista configura, o leitor-espectador refigura)" (OST, 2007. p. 34), separando a narrativa em três aspectos, quais sejam: prefiguração, configuração e reconfiguração, mímesis I, II e III, sucessivamente.

O primeiro momento da mimese é a prefiguração do campo da ação, pois "a disposição da intriga sempre se opera sobre o fundo de uma pré-compreensão partilhada do mundo da ação" (OST, 2007, p. 36). Trata-se de uma estrutura anterior à narrativa, vinda da experiência; um novelo de histórias a partir da qual se retira um fio para tecer a trama. Para Ricoeur, a trama é o que da harmonia ao desarmônico, permitindo ao leitor a compreensão do que até então era incompreensível.

É por isso que se alguma história pode ser contada, ela já está pronunciada em signos e cozida no tempo. A literatura, nesse sentido, dá azo ao que já está contido na ação humana. A mímesis I é, nesse trilho, condição de formação da narrativa.

A mímesis II guarda a configuração. A segunda mímesis é a extração de uma síntese da sucessão heterogênea de eventos. Conforme aponta Ricoeur, explicado por Hartman:

É também o ponto crucial de mediação entre tempo e narrativa, conectando ações individuais à História mais geral. O autor destaca dois elementos da configuração: esquematização e tradicionalismo. O primeiro é responsável pela inteligibilidade da narrativa, 
resultado de processos de organização e ordenação de elementos, ainda que esses não se dêem sob uma única regra. O segundo elemento, por sua vez, garante o caráter de transmissibilidade do que é engendrado, podendo incorporar, ao longo do tempo, inovações e novas sedimentações. (HARTMAN, 2015, p. 19)

Enfim, os dois elementos anteriores se ligam ao terceiro momento, que se volta ao destinatário da narrativa: o leitor, o receptor da obra. Este é o momento da "refiguração, que implica, ao mesmo tempo, uma retomada criativa da obra e uma transformação do leitor-espectador" (OST, 2007, p. 37), pois é assim que o mundo do espectador se encontra com o do texto.

Portanto, evidencia-se que a linguagem, capaz de transmitir uma experiência, não é um fim em si. “Desse modo, o que um leitor/ouvinte recebe através de um trabalho literário não é apenas o seu sentido, mas, através desse sentido, a experiência que tal trabalho pôde trazer à linguagem" (HARTMAN, 2015. p. 19). Ademais, entende-se que "assim como a experiência, dizíamos, está à espera da narrativa, assim também a narrativa, poder-se-ia afirmar agora, está à espera de leitores" (OST, 2007, p. 38).

Não sem razão, Ost assevera que a narrativa está vinculada à ética, uma vez que a literatura submete as convicções a diversas experiências de pensamento e de variações imaginativas, afinal, ela cumpre uma função de descoberta e de experimentação prática. Eis que a experiência também se dá no plano da discussão dos valores e não no da aplicação das regras morais, tendo em vista que "é exatamente nesse nível mediano, entre o registro de fatos e gestos e a prescrição de regras, que a narrativa opera: entre descrever e prescrever, contar" (OST, 2007, p. 39-40).

Também por isso se apresenta, com Leal de Oliveira (2017, p. 250), a importância do narrador como contador de 
histórias que por vezes são forçadamente esquecidas:

A narração tem a capacidade de revelar palavras e expressões que, muitas vezes, estão escondidas nas próprias palavras com as quais se narra, pois com a narração se pode quebrar o encadeamento "natural", "esperado". Ela não se pauta pelo convencimento pela racionalidade, mas pelo engajamento, pela mobilização no discurso, produzindo, assim, imaginação, preparando o espírito do ouvinte para surpresas que possibilitam a abertura para algo totalmente novo ou impensado. (MATOS, 2002, p.317).

Para mais adiante reforçar $(2017$, p. 251) que dar voz ao que foi esquecido é central:

Uma crítica ao direito só pode ser possível em face de uma articulação política do testemunho na vida social e política concretas. Caso os excluídos, os oprimidos, os sem voz, levem às cortes seus traumas (sociais ou pessoais; étnicos ou comunitários) é menos porque houve uma mudança ou uma abertura democrática da esfera jurídica em si, mas sim porque lutas (que se desenrolam há décadas) conseguiram chegar aos tribunais e "tirar a venda da Justiça". (SELIGMANN-SILVA, 2014, p.12).

É fundamental ter em conta que a memória, o testemunho e a narrativa devem caminhar em sintonia, pois do testemunho constrói-se a narrativa e da narrativa reavivam-se as memórias, que serão recontadas, debatidas e farão parte do imaginário, do simbólico e do real daquela sociedade.

A memória pertence ao passado, mas seus reflexos são sentidos no presente, e serão fundamentais ao futuro, seja ele qual for. O Brasil, entretanto, teve oportunidade de se encontrar com seu sombrio passado recente de coesão e arbítrio, na ocasião do julgamento da $\mathrm{ADPF}^{10} 153$, no qual se debateu

10 ADPF: Arguição de Descumprimento de Preceito Fundamental, instituto contido no art. $102, \S 1^{\circ}$, da $\mathrm{CF} / 88$, visa ao controle concentrado de constitucionalidade. Encontra regulação na lei 9882/99, sua função precípua é definir, com eficácia geral, se determinado ato do poder público guarda conformidade com a Ordem Constitucional vigente. 
a constitucionalidade do $\S 1^{\circ}$, do art. $1^{\circ}$ da Lei $6683 / 79$, a Lei da Anistia. No capítulo que se segue abordar-se-á o julgamento da ADPF 153 pelo Supremo Tribunal Federal, dando ênfase ao voto do Ministro Relator e do Ministro que abriu a divergência.

\section{A anistia jurídico política no Brasil como impedimento do trabalho de elaboração do passado - análise do julgamento da adpf 153 pelo stf.}

Em 29 de abril de 2010 o Supremo Tribunal Federal deu início ao julgamento da indigitada ADPF, proposta pelo Conselho Federal da Ordem dos Advogados do Brasil. Na Corte Suprema, a ação foi relatada pelo Ministro Eros Grau, encontrando divergência no voto do Ministro Ricardo Lewandowski, acompanhado pelo Ministro Ayres Britto, entretanto, ambos foram vencidos pela maioria da Corte, cujos votos seguiram o do relator.

A celeuma se deu em torno do parágrafo $1^{\circ}$ do artigo $1^{\circ}$ da Lei n. 6.683, de 19 de dezembro de 1979. Por meio da ADPF proposta pelo Conselho da Ordem dos Advogados do Brasil, ambicionou-se a declaração de não-recebimento do citado parágrafo pela Constituição, uma vez que a concessão da anistia para crimes políticos seria estendida a todos que, no período assinalado pela lei, tenham cometido crimes conexos, ou seja, crimes de qualquer natureza que sejam relacionados a crimes com motivação política.

O voto do relator prevaleceu, por ampla maioria, vedando, portanto, a revisão dos crimes cometidos no bojo do regime de exceção adotado a partir de abril de 1964, com o golpe dado pelos militares, arrimado em alguns setores privilegiados da sociedade civil. 
Na ocasião do julgamento da ADPF 153 pelo STF, o Brasil poderia ter dado um importante passo rumo à rememoração do seu passado, no entanto, a Corte Suprema impediu a revisão da Lei Anistia, que veda o julgamento dos crimes cometidos nos anos em que vigia o regime comandado pelos militares, notadamente no período compreendido entre 12 de setembro de 1961 e 15 de agosto de 1979, condenando a sociedade brasileira a um eterno vir a ser.

O relatório produzido pelo Ministro Relator consignou que os arguintes "aduziram que o recebimento (pela Constituição de 1988) do art. $1^{\circ}$, da Lei 6683/1979 induziria ao desrespeito ao dever do poder público de não ocultar a verdade", de modo que, ainda nos prolegómenos do voto vencedor, $\mathrm{m}$ o STF reconhece não se tratar de mera questão dogmática penal, senão sobre a recente história do país, sobre adquirir consciência do próprio passado, de forma a construir sua memória.

O Ministro Eros Grau adotou peculiar ótica a respeito do contexto da promulgação da norma objeto da ADPF, acrescida da maneira que a sociedade civil lidou com a redemocratização e com a anistia. Segundo seu relato, foi sob os apelos e a comoção da sociedade civil e dos membros do regime ditatorial, dos "anos de chumbo" ${ }^{11}$, que a Lei da Anistia se deu. Ao passo que, para o Ministro Lewandowski, a insatisfação popular com o regime era grande, além da crise econômica, da emissão de uma carta aos brasileiros pela comunidade jurídica, da pressão do exterior, da mudança da política externa dos Estados Unidos da América e da atroz crise de legitimidade enfrentada pelos Militares encastelados no poder.

11 Deu-se a alcunha de "anos de chumbo" ao período pós Ato Institucional $\mathrm{n}^{\circ}$ 5, em 1968, quando as liberdades sofreram mais forte repressão do regime ditatorial. 
Embora tenha entendido que o acesso a documentos históricos signifique uma forma de "exercício do direito fundamental à verdade" a Suprema Corte decidiu que os crimes cometidos pelos agentes da ditadura militar não poderiam ser objeto de investigação e punição, em notável contrassenso. O proceder adotado pelo STF parece trazer uma resposta à questão formulada por Hannah Arendt em seu texto Verdade e Política: “Será da própria essência da verdade ser impotente e da própria essência do poder enganar?" (ARENDT, 1967). Afinal, vê-se como um forte trabalho de esquecimento a respeito da ditadura militar levado adiante por aqueles que não querem ver a história ser contada sob a perspectiva dos vencidos.

Sobreleva-se o viés de distanciamento da história no voto do Relator, em especial a contada pelas vítimas da ditadura civil-militar, pelos anistiados que não pertenciam à "revolução" ${ }^{12}$, em especial quando o Ministro Eros Grau destaca o parecer do Procurador Geral da República à época, que declarou:

É evidente que reconhecer a legitimidade da Lei da Anistia não significa apagar o passado. Nesse sentido, o estado democrático de direito, para além da discussão a cerca da punibilidade, precisa posicionar-se sobre a afirmação e concretização do direito fundamental à verdade histórica. (...) Romper com a boa-fé dos atores sociais e os anseios das diversas classes e instituições políticas do final dos anos 70, que em conjunto pugnaram - como já demonstrado - por uma Lei da Anistia ampla, geral e irrestrita, significaria prejudicar o acesso à verdade histórica.

O voto vencedor parece ter se dado calcado na lógica do progresso, visto como inevitável, entretanto, violador,

12 Os defensores do regime ditatorial empregam o termo Revolução de 1964. Trata-se de mais uma tentativa de mascarar o passado, disponível em: <http://www.planalto.gov.br/ccivil_03/AIT/ait-01-64.htm> Acesso em 06 de dezembro de 2018. 
segregador, uma vez que ignora os escombros que ficam pelo caminho. Coadunando-se com o sentido criticado por Benjamin, em sua nona tese sobre a história, uma vez que faz questão de ignorar as vítimas que ficaram pelo caminho, os corpos e mentes, relativizando-os, vendo-os como provisórios, como contingências. Contudo, só os que sofreram o peso da exceção é que podem apresentar outra visão sobre a força do progresso sobre si.

Eis que o uso das palavras acompanha o falacioso discurso da "reconciliação nacional" sustentado pelos militares e defendido com unhas e dentes pelos ainda donos do poder, conforme ora se evidencia (GAGNEBIN, 2014, p. 253).

Por sua vez, o voto que abriu a divergência apresenta uma narrativa muito mais condizente com os fatos pretéritos vividos sob o império dos militares, abordando, ademais, o contexto social e histórico daqueles tristes tempos. Ainda, o voto vencido pareceu estar atento às perguntas formuladas por Márcio Seligmann-Silva (2006), senão vejamos:

Ora, como decretar-se o esquecimento de quem foi humilhado, torturado? Como pedir aos familiares que esqueçam seus familiares desaparecidos? Como pedir a uma nação que se esqueça do que aconteceu naqueles anos de chumbo? Muito pelo contrário, para reforçar-se a democracia e para a construção de um verdadeiro Estado de Direito, cabem, antes de mais nada, um dever de memória e um dever de justiça.

Neste caminho, a bandeira da reconciliação, levantada pelos defensores da Anistia, mascara o que realmente quer dizer, pois significa esquecer. Portanto, a reconciliação é a antítese da lembrança e lembrar leva a não repetir. Logo, devido à reconciliação (anistia) como prática, o esquecimento torna-se regra.

Entretanto, é interessante o alerta formulado por Reyes Mate (2011, p. 157), acerca das diferenças entre o esqueci- 
mento, na medida em que apresenta o esquecimento como desconhecimento do passado, e o esquecimento como não dar importância ao passado: "No primeiro caso, o esquecimento é ignorância e, no segundo, injustiça" - não parece que o STF possa ser taxado como ignorante.

Neste trilho, retomando o exemplo privilegiado dado pelo voto do Ministro Relator, que advoga a tese de que havia uma comoção social pela anistia, oriunda de ambos os lados, a verdade aponta no sentido da aceitação do mais fraco da força ante o poder do mais forte. Neste sentido, a "anistia ampla, geral e irrestrita", se deu muito mais para apagar o passado das atrocidades cometidas pela força bruta dos militares, e para jogar na lata de lixo da história os atos de resistência ao arbítrio perpetrado pelos militantes, notadamente incomparáveis entre si.

Ora, evidencia-se ainda hoje a luta das vítimas diretas e indiretas por justiça, verdade e memória, como nos esforços realizados pela Comissão Nacional da Verdade, ou mesmo na luta individual dos familiares das vítimas (também vítimas), ao passo que não se tem notícia de agentes da repressão buscando reparação pelo ocorrido, de modo que não é necessária uma análise mais detida para se afirmar a falsidade da simetria adotada pela Lei da Anistia. Tanto o é que "o registro do revisionismo é o da mentira" (SELIGMANN-SILVA, 2000, p. 4) uma vez que se dedica a negar o passado, senão a rescrevê-lo.

A negativa do Ministro Relator à oitiva das vítimas da ditadura civil militar brasileira, sob o manto de argumentos procedimentais, representa a bem sucedida tentativa de apagar o passado, materializada na negativa de ouvir o testemunho das pessoas que sofreram com os agentes da repressão, conforme notou Gagnebin (2014. p. 253): “essas sutilezas linguísticas remetem ao eixo principal da política 
de 'reconciliação nacional' promovida pelos militares e defendida com obstinação até hoje pelas instâncias políticas e jurídicas dos diversos governos civis".

Diante disso, é também importante encarar a rememoração no sentido entendido por Márcio Seligman-Silva (2006):

A memória do mal é uma importante contraparte da justiça e sem esta, por sua vez (por mais imperfeita que ela seja), o Estado de Direito e a Democracia não podem se construir. Os antigos donos do poder sempre declaram que esta memória do mal é apenas fruto do ódio, da vontade de vingança. Mas justamente não se trata da lei do talião, do "olho por olho, dente por dente", porque estamos diante de crimes sem-medida. Trata-se, antes, do re-conhecimento do mal e do restabelecimento da verdade. Não se pode falar de memória social e em democracia sem se levar em conta o papel da instância jurídica neste trabalho de restabelecimento da verdade dos fatos.

Em seu voto, contudo, o Ministro Lewandowski, no início do relato, sustenta:

De fato, a Lei da Anistia, longe de ter sido outorgada dentro de um contexto de concessões mútuas e obedecendo a uma espécie de "acordo tácito", celebrado não se sabe bem ao certo por quem, ela em verdade foi editada em meio a um clima de crescente insatisfação popular contra o regime autoritário.

Ao voltar à história, para captar o espírito daquele tempo, se cercou de livros, de matérias de jornal e de revistas, dando ênfase à insatisfação popular que crescia desde 1974, conforme se depreende da leitura da sua narrativa. Portanto, agindo assim, o voto perdedor se aproxima do ideal de narrador talhado por Walter Benjamin, já que "a experiência que passa de pessoa a pessoa é a fonte a que recorreram todos os narradores" (BENJAMIN, 1994, p. 198).

A ditadura brasileira, por vezes rotulada como suave ou branda, porque não matou, torturou e ocultou tantas 
pessoas quanto as da Argentina ${ }^{13}$ e do Chile $^{14}$, por exemplo, "não é somente objeto de uma violenta coerção ao esquecimento, mas também é um regime que se perpetua, que dura e contamina o presente (...), uma vez que a luta pela revisão da lei da anistia, pela abertura dos arquivos secretos e pela restituição dos restos mortais dos desaparecidos, vai além de uma luta pelo esclarecimento do passado, pois visa também à transformação do presente" (GAGNEBIN, 2014. P. 255).

Seguindo-se o trilho de Walter Benjamin, pode ser apresentada a relevância do narrador como a figura que conta a história, que a leva adiante. $\mathrm{O}$ narrador representa aquele que não deixará a memória ser apagada, o escudo contra o esquecimento, de sorte que conta a história, ouvindo os testemunhos, respeitando as tradições, contribuindo para que os relatos, os fatos verídicos não caiam no esquecimento, ou sejam falseados ao sabor dos poderosos da ocasião.

O Ministro Lewandowski, embora apresente substancioso relato fático, histórico, contextualizado e robustecido por documentos, foi vencido, em suma, derrotado pela força daqueles que não querem ver a história ser contada a contrapelo. Apesar dos seus esforços, saiu-se vencido, e com isso, viu derrotada uma das tentativas de se evitar a eterna repetição do passado. Em seu voto, agiu de acordo com o narrador talhado por Walter Benjamin, pois buscou resgatar os mortos que ficaram pelo caminho, ouviu os relatos dos vencidos, apresentou suas versões e ambicionou permitir o contar da história a contrapelo.

No capítulo que se segue pretende-se analisar, ante o

13 Disponível em: <http://temas.folha.uol.com.br/40-anos-do-golpe-militar-naargentina/24-de-marco-de-1976/ditadura-deixou-como-legado-o-consensosobre-democracia.shtml> Acesso em: 06 de dezembro de 2018.

14 Disponível em: <http://g1.globo.com/mundo/noticia/2011/08/novorelatorio-sobe-para-mais-de-40000-as-vitimas-da-ditadura-de-pinochet. html> Acesso em: 06 de dezembro de 2018. 
norte epistemológico até aqui desenvolvido, se a anistia pode ter contribuído para a permanência de uma mentalidade autoritária, manifestada nos altos índices de mortes violentas, de truculência policial, os quais parecem ser naturalizados ante a impiedosa lógica do progresso.

\section{A opção pela anistia e os perigos da repetição e da normalização do passado trágico.}

Na ocasião do julgamento sob exame, o STF perdeu histórica oportunidade de permitir ao Brasil se acertar com seu passado, notadamente sob a perspectiva até aqui exposta, na qual se defende o trabalho da rememoração política como meio de enfrentar o esquecimento forçado. Afinal, uma das práticas disseminadas pela Ditadura Civil-Militar, a tortura, por exemplo, segue comum no país, embora seja signatário de vários tratados internacionais contra esta prática deletéria.

Neste mesmo trilho asseverou Brepohl:

Se anistia aos que "cometeram crimes políticos ou conexos com estes", entendendo-se por crimes conexos, atos resultantes da repressão; em outras palavras, a anistia não deixou de ser uma auto-anistia. Apesar disso, infelizmente, o Supremo Tribunal Federal considerou a lei compatível com a Constituição. Todavia, a decisão da Corte Interamericana de Direitos Humanos caminhou em sentido contrário ao pronunciamento do STF, gerando uma situação jurídica no mínimo peculiar sobre o assunto. Até o momento, de todo modo, a lei mantém-se perfeitamente válida do ponto de vista formal. (BREHPOL, 2018, p. 329)

No que se refere ao voto do Ministro Lewandowski, na hipótese de sê-lo vencedor, a sociedade brasileira teria a oportunidade de discutir publicamente os fatos que se deram nos 21 anos de ditadura, executando-se o contrário do discurso de olhar para frente. Pois, 
a discussão e o debate no seio da sociedade civil, permite ao corpo social na sua integridade realizar um processo de elaboração do trauma histórico comparável a um luto coletivo. Deve-se lembrar que este processo é essencial para que a vida em comum no presente seja possível (GAGNEBIN, 2014, p. 255).

Ainda, a jurisdição internacional não é observada quando se trata das graves acusações de torturas e assassinatos da ditadura, sob o pretexto da reconciliação; isso significa também que o Brasil é o único país da América do Sul no qual torturadores não foram julgados e o Exército não fez uma mea culpa. (GAGNEBIN, 2014, p. 254).

$\mathrm{O}$ ato de julgar para apurar as responsabilidades dos atores da ditadura civil militar não é relevante no puro agir para colocar atrás das grades os responsáveis, pois atua também no campo do simbólico, na relevância da sociedade entender que o foi aquele tempo e notadamente conhecendo, ocupando este lugar, elaborando lutos e lutas a este respeito.

Jean Marie Gagnebin (2014, p. 255/256) sintetiza parte dos problemas causados pela manutenção da vigência da Lei da Anistia:

Não é inútil repetir que o reconhecimento oficial e social da tortura durante um regime ditatorial, estabelecido por instituições governamentais, jurídicas e objeto de discussão e de debate no seio da sociedade civil, permite ao corpo social na sua integridade realizar um processo de elaboração do trauma histórico comparável a um luto coletivo. Deve-se lembrar que este processo é essencial para que a vida em comum no presente seja possível". (...) "Assim, a questão do passado, em vez de se tornar uma herança dolorosa a ser elaborada em conjunto por todo o corpo social, é reduzida, graças às leis de reparação, a uma regulamentação de indenizações individuais. Essa violência e essas mortes são tratadas como meros acontecimentos singulares, acidentes ou incidentes do percurso, o que torna uma elaboração coletiva da violência passada e presente impossível, pois assim se reduz a memória da ditadura a histórias individuais, pessoais, casos excepcionais que devem ser resolvidos rapidamente para mais bem poderem ser esquecidos. 
A possibilidade de construir uma memória social e coletiva de tal violência é, portanto, suprimida.

Na mesma seara, Paul Ricoeur, citado por Gagnebin (2014, p. 263), define anistia como "memória impedida", pois objeta a busca por memória, verdade e justiça às vítimas diretas e indiretas do que se busca esconder, anistiar. O Brasil é um dos países em que mais há mortes violentas ${ }^{15}$, tortura e assassinatos cometidos por policiais, além de ser um dos que mais matam policiais ${ }^{16}$, do mundo. Apresenta-se como provável herança do período da ditadura militar que ainda tem forte militarização do cotidiano, a qual se manifesta na própria existência de uma Polícia Militar ${ }^{17}$, prática que não se vê nas nações mais desenvolvidas. A regra em todo o mundo é que as policias sejam formadas por civis, que certamente respeitam hierarquia e subordinação, mas não se submetem à lei própria, justiça própria, sistemas próprios, que mantém sua formação psicossocial inalterada desde o regime ditatorial.

Também por esta razão Brepohl (2018, p. 327) aponta:

Particularmente no tocante ao tema da segurança pública, dentre os diversos aspectos que podem explicar tal dilema (desigualdades sociais as mais agudas, baixa remuneração dos policiais, ausência de uma prática educacional de qualidade), um deles talvez seja o mais importante e o menos reconhecido socialmente: a herança dos governos ditatoriais e de seus respectivos aparelhos repressivos.

15 Disponível em: <https://www1.folha.uol.com.br/cotidiano/2018/06/totalde-mortes-violentas-no-brasil-e-maior-do-que-o-da-guerra-na-siria.shtml> Acesso em: 26 de novembro de 2018.

16 Disponível em:<https://www1.folha.uol.com.br/cotidiano/2017/10/1931445policiais-matam-e-morrem-mais-no-brasil-mostra-balanco-de-2016.shtml> Acesso em: 26 de novembro de 2018.

17 Disponível em: <https://canalcienciascriminais.jusbrasil.com.br/ artigos/250315736/ciclo-completo-e-a-desmilitarizacao-da-policia> Acesso em 26 de novembro de 2018. 
Para mais adiante, no mesmo artigo, arrebatar:

Muitos consideram que a violência política cometida ao longo da ditadura civil-militar faz parte do passado e o que se presencia hoje é um déficit de profissionalização no combate à violência social. Considera-se ainda que esta pode ser eliminada à medida que se supere a desigualdade social. (BREPOHL, 2018, p. 327)

Evidencia-se, entretanto, que não se pode afirmar ser a falta de memória o principal responsável pela violência que assola nosso país, todavia, ao tentar jogar o passado para debaixo do tapete, repetindo as práticas que nos levaram à violação de direitos humanos e não permitindo à sociedade que debata na arena pública os efeitos pretéritos, presentes e futuros do regime ditatorial, o STF facilita o retorno do recalcado, daquilo que foi reprimido justamente por não ter sido posto para fora.

Neste mesmo trilho aponta Oliveira (2016, p. 302):

Muito embora possa existir, em alguns contextos, um desejo do esquecimento, essa cultura do esquecer só faz incrementar uma certa alienação social, que pode ser tão perigosa quanto o próprio passado, que se quer abandonar. Há o risco da sua repetição ou de não conseguir superá-lo, simplesmente por não compreender ou mesmo não conhecer quais as relações, que se estabelecem entre esse passado, o presente e, até mesmo, um futuro que se deseja viver.

Como alternativa ao esquecimento "a proposta política da memória é interromper essa lógica da história, a lógica do progresso, que, se causou vítimas no passado, hoje exige com toda naturalidade que se aceite o custo do progresso atual" (REYES MATE, 2011, p. 163). Pois, ainda para o filósofo espanhol:

A importância política das vítimas não tem a ver tanto com as causas que defenderam, mas mais com a própria figura da vítima: que a política se constrói com mortos. O problema é a banalização 
da vida e da morte. Banaliza-se a vida quando ela é considerada como um preço para se alcançar fins políticos; e se banaliza a morte quando ela é considerada moeda de troca para a paz. Banalização, porque, no final, subordina a vida e a morte aos objetivos dos vivos. (REYES MATE, 2011, p. 163).

O remédio contra a anistia não foi ministrado no Brasil, podendo ter contribuído para a eleição à Presidência da República de um militar, que já indicou para seu ministério outros oito militares ${ }^{18}$, prática sem precedentes na recente história democrática do país. O candidato eleito defende a tortura, ${ }^{19}$ bem como um dos aludidos supostos torturadores, o General Brilhante Ustra. Ora, embora o presente espaço seja curto para tal afirmação, evidencia-se como sintoma do retorno do recalque ditatorial a eleição de um representante que admira e elogia publicamente aquele período.

Não se pretende aqui afirmar peremptoriamente que a eleição de um ex-militar, que tem como vice outro militar, em um governo composto por militares, represente o retorno dos mesmos militares que atuaram na ditadura, nem da institucionalização da tortura, ou do próprio autoritarismo, pois não é possível ainda avaliar um governo sequer iniciado. O que se apresenta causa estranheza, notadamente pelo ineditismo, mas não é bastante para que se faça detida análise acerca do retorno de um governo calcado no autoritarismo.

Certo o é, entretanto, que nas nações vizinhas Argentina e Chile, os autores de crimes nos respectivos períodos ditatoriais foram e ainda são julgados, punidos, permitindo àquelas sociedades conhecer seus algozes, contar suas his-

18 Disponível em: <https://www1.folha.uol.com.br/poder/2018/11/governobolsonaro-ja-tem-5-militares-no-primeiro-escalao.shtml> Acesso em: 27 de novembro de 2018.

19 Disponível em: <http://g1.globo.com/politica/noticia/2016/11/bolsonarodiz-no-conselho-de-etica-que-coronel-ustra-e-heroi-brasileiro.html> Acesso em: 27 de novembro de 2018. 
tórias e evitar o retorno do passado de violência e arbítrio.

Pois até mesmo os mortos correm perigo de ter sua memória alterada, uma vez que há na anistia uma resistência em procurar e identificar os desaparecidos,

tratar-se-ia não apenas de não confessar os crimes cometidos, mas, sobretudo, de afirmar que cabe ao poder político decidir o destino dos mortos e que 'as leis não escritas' dos sobreviventes, que desejam ainda respeitar a prática humana (e sagrada) do funeral e da inumação, não têm força de lei. (GAGNEBIN, 2014, p. 259).

No afã de se apresentar uma contribuição para a formação de uma sociedade mais justa, livre e democrática, em que se busque a afirmação do Estado Democrático de Direito, materializado na real efetivação da proteção dos direitos e garantias fundamentais e da dignidade da pessoa humana, ambiciona-se (longe de se ter a pretensão da comparação) uma possibilidade de sugerir um aviso de incêndio, acerca dos perigos que já chegaram.

\section{Considerações finais}

Buscou-se trazer ao debate as perspectivas políticas e históricas da memória, notadamente sob a batuta da filosofia de Walter Benjamin, pois se apresenta premente a necessidade de reconstrução da memória nacional a respeito do período da ditadura civil militar e sua manifestação no cotidiano pátrio.

É de se alarmar a constante minimização dos crimes cometidos pelos agentes da ditadura militar e a forma que seus efeitos são ignorados na atualidade, chegando-se ao ponto de se normalizar discursos e manifestos favoráveis aos torturadores, e, mesmo, defensores do retorno do período de deterioração dos valores democráticos.

As teses Sobre o Conceito de História formuladas por Walter Benjamin se amoldam como instrumento de crítica 
ao autoritarismo incrustado na sociedade brasileira, o qual poderia ser combatido por uma nova perspectiva a respeito do período hodierno, através de um olhar para o passado que aponte para o futuro, mas que, sobremaneira, narre as histórias que ficaram pelo caminho. Nesta nova história a versão dos derrotados, das vítimas, dos que nunca deixaram de morrer, poderá ser notada, contada, para evitar que se repita.

Neste particular, com a consolidação da Lei da Anistia, apesar de todos os esforços empreendidos pela Comissão Nacional da Verdade, vilipendia-se uma atenção ao presente, em especial às suas estranhas reminiscências que se perpetuam, afinal não se trata apenas de não se esquecer do passado, mas, sobremaneira, de sua atuação sobre a contemporaneidade. Rememorar fielmente o passado é, pois, um dos remédios que podem ser ministrados contra a sua repetição no presente.

Apresentam-se marcantes na sociedade brasileira os traços do passado esquecido, afinal, ainda se reprime com violência, castigo e dor os vencidos, no que se desvela como uma prática do Estado brasileiro. Romper com este hábito, com este continuum, é fundamental e indispensável para que a sociedade tome conta do Estado Democrático de Direito, cobrando, debatendo, discutindo as origens do arbítrio, para que nunca se esqueça, para que não se repita.

\section{Referências}

AQUINO, João Emiliano Fortaleza de. Primo Levi, leitor de Freud: O falseamento das lembranças e o testemunho. Cadernos Benjaminianos, [S.1.], n. 7, p. 115-131, dez. 2013. ISSN 2179-8478. Disponível em: <http:/ / www.periodicos. letras.ufmg.br/index.php/cadernosbenjaminianos/article/ view/6049/5229>. Acesso em: 13 nov. 2018 
ARENDT, Hannah. Verdade e Política. Entre o Passado e o Futuro. 1968.

BENJAMIN, Walter. Experiência e Pobreza. In: Walter Benjamin o Anjo da História. Org. e trad. João Barrento. 2. ed. 1. reimp. Belo Horizonte: Autência Editora, 2016. P. 85-90

BENJAMIN, Walter. Sobre o conceito da História. In: Walter Benjamin o Anjo da História. Org. e trad. João Barrento. 2. ed. 1. reimp. Belo Horizonte: Autência Editora, 2016. P. 09-20

BENJAMIN, Walter. “O Narrador. Considerações sobre a obra de Nikolai Leskov". In: Magia e técnica, arte e política: ensaios sobre literatura e história da cultura. 7. Ed. São Paulo: Brasiliense, 1994.

BRASIL. Supremo Tribunal Federal. Arguição de Descumprimento de Preceito Fundamental 153. Brasília, 29 de abril de 2010.

BREPOHL, Marion, GONÇALVES, Marcos e GABARDO, Emerson. As violências do estado de exceção e a defesa da memória contra a invisibilidade dos grupos vulneráveis. In: Revista Brasileira de Estudos Políticos. N 117, jul./dez. 2018. UFMG: Belo Horizonte, p. 321-361.

GAGNEBIN, Jean Marie. Limiar, aura e rememoração. Ensaios sobre Walter Benjamin. São Paulo: Editora 34, 2014.

GAGNEBIN, Jean Marie. Memória, história, testemunho. In: Memória e (Res)sentimento indagações sobre uma questão sensível. Orgs. Stella Bresciani e Márcia Naxara. 2. ed. Campinas: Editora Unicamp, 2004. P. 83-92.

HARTMANN, Sara. Walter Benjamin e Paul Ricoeur: narração e experiência por vir. Cadernos Benjaminianos, [S.1.], n. 9, p. 13-23, out. 2015. Disponível em: <http://www.periodicos.letras.ufmg.br/index.php/cadernosbenjaminianos/ article/view/8598/8495>. Acesso em: 12 nov. 2018. 
LEVI, Primo. Os afogados e os sobreviventes: os delitos, os castigos, as penas, as impunidades. Paz e Terra. 2ed. 175 p. 2004.

LOWY, Michael. Walter Benjamin: aviso de incêndio. Uma leitura das teses "Sobre o conceito de história". São Paulo: Boitempo, 2014.

MATE, Reyes. Meia-noite na história. Comentários às teses de Walter Benjamin sobre o conceito de história. São Leopoldo: Ed. Unisinos, 2011.

MOREIRA, Nelson Camatta e DE PAULA, Rodrigo Francisco. Identidade e memória no constitucionalismo brasileiro. $\mathbf{O}$ que é um pai, hoje?: Reflexões nas fronteiras entre direito e psicanálise. Org. Vescovi, Renata Conde. Vitória: FDV publicações, 2016. p. 157.

OLIVEIRA, Antonio Leal de, GOMES, Raoni Vieira. Seletividade racial no sistema penal brasileiro: apontamentos para a reconstrução da memória racial nacional a partir das teses de Walter Benjamin. Revista Brasileira de Ciências Criminais, vol. 135. São Paulo: RT, 2017, p. 73.

OLIVEIRA, Antonio Leal de. $\mathrm{O}$ direito à memória como um dos fundamentos da dignidade humana: memória política e justiça para as vítimas do progresso. Tese (doutorado) em direito. PUC-RJ, 312 p.

OLIVEIRA, Natália Silva Teixeira Rodrigues de. Poder e (in) tolerância: a importância da memória na reconstrução de uma identidade.In: Revista Brasileira de Estudos Políticos. N112. Jan/jun 2016. UFMG: Belo Horizonte, p. 299-338.

OST, François. Contar a Lei, as fontes do imaginário jurídico. São Leopoldo - RS: Editoria Unisinos, 2007.

RICOEUR, Paul. Memória, História, Esquecimento. In "Haunting Memories? History in Europe after Authori- 
tarianism". 8 de Março de 2003, Budapeste, Hungria.

SELIGMANN-SILVA, Márcio, "Anistia e (in)justiça no Brasil: o dever de justiça e a impunidade." In: Revista Literatura e Autoritarismo: memórias da repressão, n. 9, 2006. Disponível em: < http:/ / coralx.ufsm.br/grpesqla/revista/ num09/art_02.php>. Acesso em: 26 de junho de 2018.

SELIGMANN-SILVA, Márcio. Auschiwitz: história e memória. In: Pro-Posições, vol. 1, n. 5. 78-87.

Recebido em 10/12/2018

Aprovado em 03/06/2019

Nelson Camatta Moreira

E-mail:nelsoncmoreira@hotmail.com

Raoni Vieira Gomes

E-mail: raonivgomes@gmail.com 